TITLE:

\title{
Mahale: A single flu epidemic killed at least 11 chimps
}

$\operatorname{AUTHOR}(\mathrm{S})$ :

CITATION:

Mahale: A single flu epidemic killed at least 11 chimps. Pan Africa News 1995, 2(2): 3-4

ISSUE DATE:

1995-10

URL:

http://hdl.handle.net/2433/143330

RIGHT:

Copyright (C) Pan Africa News. 


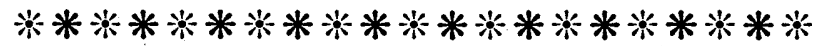

The next article concerns an epidemic in Mahale Mountains National Park. At the end of September 1993 a flu-like illness struck almost all $M$ group chimpanzees with serious consequences. The contributor is Kazuhiko Hosaka, a Kyoto University graduate student who did research on M group from March, 1993 - February, 1994.

\section{Mahale: A single flu epidemic killed at least 11 chimps}

Events began at the end of September, 1993. Pulin, an approximately 23 year old female chimpanzee, was found dead in the dry Kasiha riverbed by Dr. K. Kawanaka as he returned to Kansyana Research Station in the late evening of October 7. Although many chimps were suffering from a flu-like illness at the time, we had not considered it extraordinary since we knew such an outbreak occurred at least once every year. However, some members of the study group were missing and those members all usually followed the main party including the alpha male. The longer they remained missing the stronger became our conviction that they had succumbed to some terrible illness.

We think at least 11 chimps fell victim to this epidemic. Eight of them (three adult females, two adolescent males, three infants) died during the epidemic itself. Three (an old male, an old female, a juvenile female) died a few months later after becoming emaciated.

The deaths of the victims had vital meaning for the lives of others. For example, many young chimpanzees were orphaned. Pippi, Pulin's three years and five months-old daughter, passed at least two helpless nights in a fig tree just above her mother's corpse. When we finished collecting Pulin's body in a flour sack and began to move, Pippi, who had sometimes coughed weakly while eating fig fruits, started to whimper, quickly climbed down and finally ran into the bush crying 
loudly. Far away in the direction she headed, we heard many pant-hoots and we hoped she would reach others. Fortunately, nine days later we saw her walking with a large group. Although she has not been adopted by any non-relative female she has survived and looks healthy at present.

On the other hand, for Brahim, a small infant aged two years and five months, it was too early to lose his mother. When I saw him being carried on the back of a non-kin adolescent male I could not help suspecting that his mother was already dead. That hunch became stronger when the decomposed corpse of an adult female chimp was discovered not far from the area five days later. Brahim had no time to feel depressed; all he could do was try to survive. He searched for any chimp that would carry him on his/her back. Most chimps ignored him although no one was cruel to him. Once he whimpered toward a nearby chimp, that individual could not ignore him and allowed him to ride on the back. At least two adult males, two adult females and three adolescent males ranged with Brahim. However, we saw him with others for only three days and he has not reappeared since. Obviously the death of the mother chimp is of serious significance to her offspring's survival.

It is not certain where they caught this fatal disease. The virus might have been brought in by another chimpanzee group. Another fearful posibility was that an ill human was the origin since chimps are susceptible to human diseases. In some instances of flu epidemics at Mahale, both chimps and humans (researchers, and local inhabitants) suffered simultaneously and so it is plausible that either chimp or human was the initial carrier of the virus. However, in this case there was no flu epidemic among the human residents. I did however observe that some tourists to Mahale came to see chimps even though they had caught a bad cold during the long, chilly night journey on Lake Tanganyika.

Whatever the truth we now needed to consider how to protect the chimps from catching human diseases. We were truly apprehensive for the future of $\mathbf{M}$ group, which had decreased from quite a large unit-group of 101 chimps to 75 chimps by December 1994 (This unit-group also decreased in size in 1989-1990 when a lion was on the prowl in the area) and so I made the following proposals to the Park Warden of the Mahale Mts. National Park.

1. No one who is ill should not be permitted to go into the forest. Even healthy persons must not go closer than 5 meters to chimps.

2. There should be no smoking, eating or drinking in the forest and no feeding chimps.

3. No person should defecate in the forest. If necessary, you have to either make or look for suitable holes in which to defecate and cover them completely.

4. The people living inside $\mathbf{M}$ group's range must not scatter garbage around their houses but must make a large hole in which to dispose of, burn and cover the remains of garbage.

The administration of MMNP was quite cooperative. They issued two notices in Kasiha village (the only residential area inside $M$ group's range). One was to give directions about garbage disposal. The other to declare strict action against those who violated park regulations and that only researchers, field assistants, park staff and their immediate families can live inside the park. This improved conditions because the population in Kasiha had increased since the construction of the tourist lodge and our research station proved attractive to the unemployed. In the beginning of 1993 we went through a horrifying outbreak of cholera and amoebic dysentry in Kasiha that had invaded from the northern villages outside MMNP and killed some of my own acquaintances.

Some problems still needed to be resolved. Although we know it is likely that chimps can be infected by pathogens brought to the forest by humans, park guides cannot control some tourists' apparently thoughtless behavior not only because most of the guides do not speak English and the tourists do not speak Swahili but they also feel intimidated by their "important" guests.

On the part of the researchers, since we owe our long-term accomplishments to the cooperation of the local Tongwe people and the staff of MMNP we have a responsibility to further their education about the invaluable wildlife treasure contained in the park, to teach them to conserve it, and to make every effort to reward their precious contribution by the improvement of their standard of living.

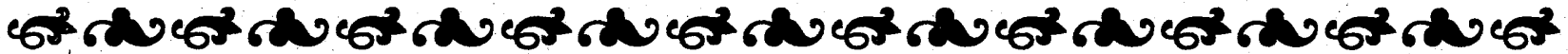

